\title{
Endothelial barrier dysfunction caused by LPS correlates with phosphorylation of HSP27 in vivo
}

\author{
S. Hirano ${ }^{1,2}$, R.S. Rees ${ }^{1}$, S.L. Yancy ${ }^{2}$, M.J. Welsh ${ }^{2}$, D.G. Remick ${ }^{3}$, T. Yamada ${ }^{4}$, J. Hata ${ }^{4}$ \\ and R.R. Gilmont ${ }^{1}$ \\ ${ }^{1}$ Department of Surgery, ${ }^{2}$ Cell and Developmental Biology, and ${ }^{3}$ Pathology, University of Michigan \\ Medical Center, Ann Arbor, MI, USA, ${ }^{4}$ Department of Pathology, Keio University, School of Medicine, \\ Tokyo, Japan
}

Received 25 April 2003; accepted 23 October 2003

Keywords: endothelial cells, heart, hydrogen peroxide, LPS, lung injury, TNF $\alpha$

\begin{abstract}
Lung edema during sepsis is triggered by formation of gaps between endothelial cells followed by macrophage infiltration. Endothelial gap formation has been proposed to involve changes in the structure of the actin filament cytoskeleton. Heat shock protein 27 (HSP27) is believed to modulate actin filament dynamics or structure, in a manner dependent on its phosphorylation status. We hypothesized that HSP27 may play a role in endothelial gap formation, by affecting actin dependent events in endothelial cells. As there has been no report concerning HSP27 in lung edema in vivo, we examined induction and phosphorylation of HSP27 in lung following LPS injection, as a model of sepsis. In lung, HSP27 mainly localized in capillary endothelial cells of the alveolus, and in smooth muscle cells of pulmonary arteries. HSP27 became significantly more phosphorylated at $3 \mathrm{~h}$ after LPS treatment, while the distribution of HSP27 remained unchanged. Pre-treatment with anti-TNF $\alpha$ antibody, which has been shown to reduce lung injury, blocked increases in HSP27 phosphorylation at $3 \mathrm{~h}$. HSP27 phosphorylation was also increased in cultured rat pulmonary arterial endothelial cells (RPAEC) by treatment with TNF $\alpha$, LPS, or $\mathrm{H}_{2} \mathrm{O}_{2}$. This phosphorylation was blocked by pretreatment with SB203580, an inhibitor of the upstream kinase, p38 MAP kinase. Increased endothelial permeability caused by $\mathrm{H}_{2} \mathrm{O}_{2}$ in vitro was also blocked by SB203580. The amount of actin associated with HSP27 was reduced after treatment with LPS, or $\mathrm{H}_{2} \mathrm{O}_{2}$. In summary, HSP27 phosphorylation temporally correlated with LPS induced pathological endothelial cell gap formation in vivo and in a cell culture model system. This is the first report of increased HSP27 phosphorylation associated with pathological lung injury in an animal model of sepsis.
\end{abstract}

Abbreviations: ARDS, adult respiratory distress syndrome; BSA, bovine serum albumin; DMEM, Dulbecco minimal essential medium; FCS, fetal calf serum; FITC, fluorescein isothiocynate; H\&E, hematoxylin and eosin; HRP, horseradish peroxidase; HSP27, heat shock protein 27; IEF, isoelectric focusing; IL, interleukin; IPB, immunoprecipitation buffer; LPS, lipopolysaccharide; MAP kinase, mitogen activated protein kinase; MHC, myosin heavy chain; MLCK, myosin light chain kinase; MTT, 3-(4,5-dimethyl-thiazocyl-2-yl)2,5-diphenyltetrazolium bromide; PBS, phosphate buffered saline; PVDF, polyvinylidene fluoride; RPAEC, rat pulmonary arterial endothelial cells; SDS, sodium dodecyl sulfate; TNF $\alpha$, tumor necrosis factor $\alpha$ 


\section{Introduction}

Adult respiratory distress syndrome (ARDS) occurs in $18-25 \%$ of sepsis syndrome patients and results in up to $90 \%$ mortality. ARDS associated pulmonary edema, poorly compliant lungs, and refractory hypoxemia are due to impairment of endothelial barrier function and advancement of neutrophils through the endothelium into the tissues (reviewed in Martin and Silverman, 1992).

The vascular endothelium is a semi-selective diffusion barrier between the blood plasma and interstitial tissue. Inter-endothelial cell gap formation with loss of barrier function leads to neutrophil infiltration and tissue edema. Trans-endothelial permeability is increased by endothelial cell shape change and disruption of tight junctions between cells. It has been shown that reorganization of the actin-containing cytoskeleton is essential for shape changes and loss of tight junction integrity associated with increased permeability in endothelial cells (Alexander et al., 1988; Phillips et al., 1989; Shasby et al., 1982).

HSP27 was identified as an inhibitor of actin polymerization when it was co-purified with vinculin from avian smooth muscle Miron et al., 1991). Several reports indicate that HSP27 plays an important role in regulating the actincontaining cytoskeletal structure. HSP27 can inhibit actin polymerization in vitro (Miron et al., 1991) and this ability appears to be dependent on its phosphorylation status (Benndorf et al., 1994). In cell lines transfected to overexpress HSP27, cortical actin arrays were increased as was pinocytotic activity (Lavoie et al., 1993a). These increases were not observed in cell lines transfected with a mutant form of HSP27 incapable of being phosphorylated (Lavoie et al., 1993a). Microfilaments in cells transfected to over-express HSP27 were more stable to heat-shock treatment or cytochalasin D treatment (Lavoie et al., 1993b, 1995). Thus, HSP27 can affect actin filament structure by a mechanism that depends on the phosphorylation state of HSP27.

Phosphorylation of HSP27 is induced by a number of agents or treatments that cause edema. TNF $\alpha$ treatment, which causes lung edema in sheep (Horvath et al., 1988), induced phosphorylation of HSP27 in endothelial cells (Arrigo, 1990; Robaye et al., 1989). Thrombin, another agent capable of disrupting the barrier function of endothelial cells (Phillips et al., 1989), induces HSP27 phosphorylation (Mendelsohn et al., 1991). Treatment of cultured endothelial cells with hydrogen peroxide $\left(\mathrm{H}_{2} \mathrm{O}_{2}\right)$ caused increased endothelial cell monolayer permeability (Gilmont et al., 1996) and phosphorylation of HSP27 (Huot et al., 1997). Furthermore, $\mathrm{H}_{2} \mathrm{O}_{2}$-induced endothelial microfilament fragmentation was blocked by an inhibitor of p38 mitogen activated protein (MAP) kinase, which is an upstream kinase involved in HSP27 phosphorylation (Huot et al., 1997). These reports imply that HSP27 phosphorylation may be involved in loss of endothelial barrier function. Recently, p38 MAP kinase activation was reported to be a critical step in pertussis toxin-induced increased endothelial permeability, and phosphorylation of HSP27 was suggested as an effecter of p38 MAP kinase (Garcia et al., 2002). We examined expression or phosphorylation of HSP27 in the in vivo and in vitro models of sepsis-induced pulmonary edema.

\section{Materials and methods}

\section{Sepsis model}

Adult, male Sprague-Dawley rats (approximately $200 \mathrm{~g}$ ) were used in these experiments. The sepsis group (18 rats) were given intraperitoneal injections of LPS (E. coli. serotype 0127:B8, Sigma, St Louis, MO, USA) $2 \mathrm{mg} / \mathrm{kg}$ from a $2 \mathrm{mg} / \mathrm{ml}$ stock solution in phosphate buffered saline (PBS) and were euthanized in 
groups of three at 1, 3, 6, 12, 24, and $48 \mathrm{~h}$ after injection. Control groups consisted of 3 rats without any treatment and 3 rats injected with $1 \mathrm{ml} \mathrm{PBS} / \mathrm{kg} 12 \mathrm{~h}$ before euthanasia. The hearts and lungs were harvested, cooled immediately on dry ice and store in $-80^{\circ} \mathrm{C}$ prior to RNA isolation and protein analysis.

\section{Immunohistochemistry}

Rats $(n=3)$ were euthanized at each time-point after the treatment following exposure of the trachea under anesthesia. The lungs were initially fixed by in situ tracheal instillation with $4 \%$ formaldehyde in PBS. After removal, they were immersed in the same fixative at room temperature for 4 days. The left lobes were then cut horizontally and embedded in paraffin. Sections (4 $\mu \mathrm{m}$ thick) were prepared and stained with hematoxylin and eosin (H\&E). Immunohistochemical stainings with rabbit anti-rodent HSP27 polyclonal antibody (1/ 500; Anti-HSP25, Stressgen Biotechnologies Corp., Victoria, BC, Canada) was performed using indirect reactions with a horseradish peroxidase (HRP) conjugated-secondary antibody.

\section{Anti-TNFa neutralizing antibody treatment}

Antibody group animals (9 rats) were pretreated with $1 \mathrm{ml}$ of anti-TNF $\alpha$ neutralizing rabbit antisera (Remick et al., 1990) $1 \mathrm{~h}$ before LPS injection. LPS only group (9 rats) were injected with normal rabbit serum. Treated and untreated rats were euthanized at 1,3 , and $12 \mathrm{~h}$ $(n=3)$ after LPS injection, and organs were harvested as described previously.

\section{Plasma TNF level}

Plasma was harvested from anti-TNF $\alpha$ antibody treated and normal rabbit serum treated rats at 1 or $3 \mathrm{~h}$ after LPS injection as well as from control untreated rats before the organs were harvested. TNF $\alpha$ levels were determined by bioassay utilizing the WEHI 164 sub clone 13 cell line and previously published methods (Eskandari et al., 1990). Samples were serially diluted in 96 well plates and WEHI cells in suspension (with actinomycin D) were added. The plates were allowed to incubate overnight at $37^{\circ} \mathrm{C}$ followed by addition of MTT-Tetrazolium (Sigma). Plates were returned to the incubator for an additional $4 \mathrm{~h}$ followed by addition of acidified isopropanol overnight. Readings were performed at $550 \mathrm{~nm}$ with background subtraction at $630 \mathrm{~nm}$. TNF $\alpha$ values were then extrapolated from a standard curve of human recombinant $\mathrm{TNF} \alpha$ (Cetus Corporation, Emeryville, CA, USA) that was employed in the same assay.

\section{Isolation of RNA}

RNA was isolated from frozen tissues according to method of Chomczynski and Sacchi (Chomczynski and Sacchi, 1987). Briefly, samples were homogenized in a solution of $4 \mathrm{~mol} /$ $\mathrm{L}$ guanidine isothiocynate, $25 \mathrm{mmol} / \mathrm{L}$ sodium citrate, $0.5 \%$ N-lauroyl sarcosine, and $0.1 \%$ mercaptoethanol with a polytron 3000 homogenizer (Brinkman Instruments Inc., Westbury, NY, USA). Total RNA was extracted with phenol-chloroform-isoamyl alcohol solution and precipitated with ethanol. Following a second ethanol precipitation, RNA was resuspended in water and quantified by spectrophotometric measurement.

\section{Northern blot analysis of HSP27 mRNA}

RNA samples $(20 \mu \mathrm{g})$ were denatured by incubation at $65^{\circ} \mathrm{C}$ for $10 \mathrm{~min}$ in a buffer containing $20 \mathrm{mmol} / \mathrm{L}$ Hepes (PH 7.8), 1 $\mathrm{mmol} / \mathrm{L}$ EDTA, $6 \%$ formaldehyde, and $50 \%$ formamide. RNA samples were separated by electrophoresis in $1.2 \%$ agarose gels containing $20 \mathrm{mmol} / \mathrm{L}$ Hepes, $1 \mathrm{mmol} / \mathrm{L}$ EDTA, and 6\% formaldehyde and transferred onto nylon 
membranes (Biotrace HP; Gelman Sciences, Ann Arbor, MI, USA). After the blots were incubated for $2 \mathrm{~h}$ at $42^{\circ} \mathrm{C}$ in solution containing $0.5 \% \mathrm{SDS}, 400 \mathrm{mmol} / \mathrm{L} \mathrm{NaH}_{2} \mathrm{PO}_{4}(\mathrm{PH}$ 7.2), $1 \mathrm{mmol} / \mathrm{L}$ EDTA, $1 \mathrm{mg} / \mathrm{ml} \mathrm{BSA}$, and $50 \%$ formamide, $\left[{ }^{32} \mathrm{P}\right]$-labeled probes were added to the mixtures, which were then allowed to incubate for an additional $18 \mathrm{~h}$. After hybridization, blots were washed twice in wash solution $(1 \times \mathrm{SSC}, 0.1 \% \mathrm{SDS})$ at $42^{\circ} \mathrm{C}$, followed by high stringency washes in buffer containing $0.2 \times \mathrm{SSC}, 0.1 \% \mathrm{SDS}$ twice at $65^{\circ} \mathrm{C}$ for cDNA probes or at $55^{\circ} \mathrm{C}$ for oligonucleotide probes. Radiolabeled probes for HSP27 were prepared from a full coding length cDNA (accession number M86389) by using [ $\left.{ }^{32} \mathrm{P}\right]$ $\mathrm{dCTP}$ in a random primer reaction (Random primers DNA labeling system, Life Technologies Inc., Gaithersburg, MD, USA). Radiolabeled probes for 18s RNA were prepared with $\left[{ }^{32} \mathrm{P}\right]-\mathrm{dATP}$ by a tailing reaction using terminal deoxynucleotide transferase. The oligonucleotide sequence 5'-ACGGTATCTGATCGTCTTCGAACC-3' was used to hybridize to 18s ribosomal RNA (Szyf et al., 1990) as a standard. RNAs were detected by autoradiography (Fuji RX films) following storage at $-80^{\circ} \mathrm{C}$ with intensifying screens. Relative quantities of HSP27 mRNA were determined by laser densitometry (Biorad GS-700 densitometer) and were normalized to 18s RNA.

\section{Determination of phosphorylation status of HSP27}

Frozen tissue samples were homogenized in an extraction buffer which contained $9 \mathrm{~mol} / \mathrm{L}$ urea, $2 \%$ carrier ampholytes $\mathrm{pH} 3.0-10.0$ (Bio-Rad), 2\% CHAPS and 2\% 2-mercaptoethanol. Protein concentration was determined using a modified Bradford assay (Louis and Lewis, 1985). Isoelectric focusing (IEF) was carried out essentially described previously (Smoyer et al., 1996) using a model 111 Mini IEF cell (BioRad, Hercules, CA, USA). Briefly, samples were loaded into the IEF gels contained 2\% ampholine pH 3.0-10.0 (BioRad) and $6 \mathrm{~mol} / \mathrm{L}$ urea. Isoelectric focusing was performed at $100 \mathrm{~V}$ for $15 \mathrm{~min}, 200 \mathrm{~V}$ for 15 min and $450 \mathrm{~V}$ for $90 \mathrm{~min}$. Protein was transferred immediately after electrophoresis to polyvinylidene fluoride (PVDF) membranes (Millipore Corporation, Bedford, MA, USA) by semi-dry blotting apparatus (Pharmacia, Piscataway, NJ, USA). Membranes were blocked with 5\% powdered milk in PBST and incubated with a monoclonal antibody directed against HSP27 (Bitar et al., 1991) for $2 \mathrm{~h}$. Following washing, membranes were incubated with HRP-conjugated secondary antibody against mouse IgG (Jackson Immuno Research Laboratories Inc., West Grove, PA, USA) for $1 \mathrm{~h}$. Detection was carried out by Western Blot Chemiluminescence Reagent Plus (NENTM Life Science Products, Boston, MA, USA). Band densities were determined using a Model GS-700 Imaging Densitometer. Multiple exposures were used to ensure that band densities fell within the linear range of the film. The density values (area $\times$ density) of mono-phosphorylated, di-phosphorylated and un-phosphorylated forms of HSP27 were determined for each sample. The phosphorylation status was calculated using the formula, (di- + monophosphorylated)/unphosphorylated.

\section{Determination of protein expression}

Frozen tissue samples were homogenized in an extraction buffer which contained $10 \mathrm{mmol} / \mathrm{L}$ Tris-HCl, $\mathrm{pH} 7.4 ; 150 \mathrm{mmol} / \mathrm{L} \mathrm{NaCl} ; 1 \mathrm{mmol} /$ L EDTA; 0.1\% SDS; 1\% Triton X-100. Forty $\mathrm{mg}$ protein of each sample was separated by SDS PAGE followed by western blotting as described above. The blots were incubated with a polyclonal antibody directed against HSP27 were re-probed with a monoclonal antibody directed against all forms of actin (Sigma). Bands density values were determined using 
NIH image, and the density values of HSP27 were normalized to actin and reported as relative expression compared to non-treated samples.

\section{Cell culture}

Rat pulmonary arterial endothelial cells (RPAEC) (passage 10 to 16) were cultured in DMEM/F-12 medium (GibcoBRL, Grand Island, NY, USA) supplemented with 5\% fetal calf serum (FCS), $50 \mu / \mathrm{ml}$ penicillin and $50 \mu /$ $\mathrm{ml}$ streptomycin (GibcoBRL) in a humidified incubator containing an atmosphere of 5\% $\mathrm{CO}_{2}$ and $95 \%$ air. RPAEC cultures were treated with $10 \mathrm{ng} / \mathrm{ml} \mathrm{LPS}, 10 \mathrm{ng} / \mathrm{ml} \mathrm{TNF} \alpha$, or various concentration of $\mathrm{H}_{2} \mathrm{O}_{2}$ for $30 \mathrm{~min}$ before determining the phosphorylation status of HSP27, as described above. Some cells were pre-treated with an inhibitor of p38 MAP kinase, SB203580 (Calbiochem) $(20 \mu \mathrm{mol} / \mathrm{L})$ for $20 \mathrm{~min}$ prior to these treatments.

\section{Endothelial cell permeability assay}

Permeability assay was performed as described previously (Gilmont et al., 1996), except that 70 kDa FITC-dextran (FD-70, Sigma) was used in this study. Briefly, pulmonary endothelial cells were grown for 2 additional days after reaching confluence on transparent $3-\mu \mathrm{mol} / \mathrm{L}$ pore, high pore density Falcon $25 \mathrm{~mm}$ filter inserts in 6-well plates. Filter units were floated with the aid of Styrofoam collar in $30 \mathrm{ml}$ of Hank's balanced solution and overlaid with 2 $\mathrm{ml}$ Hank's solution containing $1 \mu \mathrm{g} / \mathrm{ml}$ FD-70. Aliquots $(200 \mu \mathrm{l})$ were taken at $5 \mathrm{~min}$ interval from the bottom vessel that was maintained at $37^{\circ} \mathrm{C}$ with constant stirring, and the diffusion rate was determined by linear regression analysis following $30 \mathrm{~min}$ of sampling. The cells were washed twice and $2 \mathrm{ml}$ of medium without glutamate was added to each well. Cells were treated with $200 \mu \mathrm{mol} / \mathrm{L} \mathrm{H}_{2} \mathrm{O}_{2}$ for $1 \mathrm{~h}$ with or without pretreatment with SB203580
(20 $\mu \mathrm{mol} / \mathrm{L}$ ) for $20 \mathrm{~min}$ before another set of samples was taken. After the second diffusion rate determination, differences in diffusion rates before and after treatments were expressed as percent change from the first value. Three independent experiments were performed.

\section{Immunoprecipitation with HSP27 polyclonal antibody}

RPAEC cultures were treated with $10 \mathrm{ng} / \mathrm{ml}$ LPS (Sigma), $10 \mathrm{ng} / \mathrm{ml}$ TNF $\alpha$ (Sigma) or 200 $\mu \mathrm{mol} / \mathrm{L} \mathrm{H}_{2} \mathrm{O}_{2}$ for $10 \mathrm{~min}$ before being washed $2 \times$ with PBS and solubilized in $1 \mathrm{ml}$ of immunoprecipitation buffer (IPB). IPB contained $50 \mathrm{mmol} / \mathrm{L}$ Tris $(\mathrm{pH} \mathrm{7.5),} 5 \mathrm{mmol} /$ $\mathrm{L}$ ethylenedinitrolo tetraacetic acid, 150 $\mathrm{mmol} / \mathrm{L} \mathrm{NaCl}, 0.5 \%$ Triton X-100, 0.5\% sodium deoxycholate, and a protease inhibitor cocktail (Complete, Boehringer Mannheim, Indianapolis, IN, USA). After brief centrifugation ( $5 \mathrm{~min}$ at $5000 \mathrm{~g}$ ), lysates were precleared by incubation with $30 \mu \mathrm{l}$ of protein G-sepharose (Pharmacia) for 30 min followed by centrifugation ( $2 \mathrm{~min}$ at $5000 \mathrm{~g}$ ). Lysates were then incubated with $5 \mu \mathrm{l}$ of a rabbit polyclonal antibody against rodent HSP27 (Stressgen) for $1 \mathrm{~h}$ at $4^{\circ} \mathrm{C}$. The antibody incubation mixture was then incubated with $30 \mu \mathrm{l}$ of protein $\mathrm{G}$ sepharose for $30 \mathrm{~min}$ followed by centrifugation for $2 \mathrm{~min}$ at $5000 \mathrm{~g}$. The protein G-sepharose pellets were washed $5 \times$ with IPB. After washing, the pellets were boiled in $60 \mu$ of SDS sample buffer for $5 \mathrm{~min}$ and $20 \mu \mathrm{l}$ of each sample was separated by SDS-PAGE, followed by western blotting using a monoclonal antibody directed against $\beta$-actin (Sigma). The same blots were re-probed with a monoclonal antibody directed against HSP27. The ratios of the band density values of $\beta$-actin to HSP27 were calculated and normalized to the control sample of each experiment. The experiment was repeated three times. 


\section{Statistical analysis}

Data from all experimental groups were expressed as mean \pm SEM. An unpaired students $t$-test was used to compare differences between control and experimental groups. Statistical significance was defined as $p<0.05$.

\section{Results}

Induction and phosphorylation of HSP27 in LPS treated rats

Northern blot analysis was used to determine if LPS treatment affected steady state HSP27 mRNA levels. We examined heart as well as lung for a comparison because HSP27 is known to be abundant in heart (Lutsch et al., 1997) and heart is more resistant to septic syndrome. HSP27 mRNA was maximally induced by $12 \mathrm{~h}$ after LPS injection in heart, while it was only slightly increased in lung (Figure 1A). Although there was a robust increase in mRNA in heart after LPS treatment, HSP27 protein levels remained unchanged in both heart and lung and there was no significant difference at 12 and $24 \mathrm{~h}$ compared to control (Figure 1C). Phosphorylation status of HSP27 was also determined by IEF followed by Western blotting. The phosphorylation ratio increased significantly at $3 \mathrm{~h}$ after treatment both in heart and lung (Figure 1B). The peak increase in phosphorylation was more dramatic in lung than in heart.

\section{Histological and immunohistological findings in LPS treated lungs}

To confirm the effect of low dose LPS treatment, the lungs of control and treated rats were examined by $H \& E$ staining. By $3 \mathrm{~h}$ after injection, macrophage and neutrophil infiltration in alveoli was observed, and alveolar walls were thickened in LPS treated lungs (Figure 2B) when compared to control lungs treated with PBS (Figure 2A). To determine which cells expressed HSP27 in lungs, immunohistological staining with anti-HSP27 antibody was performed, and positive staining was observed in capillary endothelial cells in alveoli (Figure 2C) and in smooth muscle cells of pulmonary arteries (data not shown). The population of the cells expressing HSP27 in alveoli remained unchanged after LPS injection, as macrophages and neutrophils did not stain for HSP27 (Figure 2D). These data suggest that changes in the phosphorylation status of HSP27 in lung is due to the change in the phosphorylation status of HSP27 in capillary endothelial cells of the alveoli and/or in the smooth muscle cells.

\section{Effect of anti-TNF $\alpha$ antibody on changes in HSP27 in lung and heart}

Because $\mathrm{TNF} \alpha$ has been shown to be a key mediator of LPS induced sepsis syndrome (Beutler et al., 1985; Tracey et al., 1987), we examined the effect of pretreatment with anti$\mathrm{TNF} \alpha$ antibody. Anti-TNF $\alpha$ antibody pretreatment appeared to have no effect on HSP27 mRNA induction either in the heart or lung at

\footnotetext{
Figure 1. (opposite) Induction and phosphorylation of HSP27 after LPS injection. (A) Changes in HSP27 mRNA levels following LPS injection were determined by Northern blot analysis. White columns (heart) and black columns (lung) represent the relative expression of HSP27 mRNA normalized to 18sRNA compared to the control level of each group. The right panel shows representative blots. (B) HSP27 phosphorylation in heart and lung after LPS injection. P/un-p represents the phosphorylation ratio (di- + mono-/ unphosphorylated form). The right panel shows a portion of a representative IEF Western blot of lung tissues. $0 \mathrm{p}$, $1 \mathrm{p}$, or $2 \mathrm{p}$ represent non, mono, di-phosphorylated form of HSP27, respectively. (C) Changes in HSP27 protein levels following LPS infection were determined by SDS PAGE followed by western blotting. White columns (heart) and black columns (lung) represent the relative expression of HSP27 normalized with actin and compared with non-treated lungs (n). The blots used for HSP27 expression were reprobed with antibody against actin to normalize. ${ }^{*} p<0.05$ vs. control.
} 

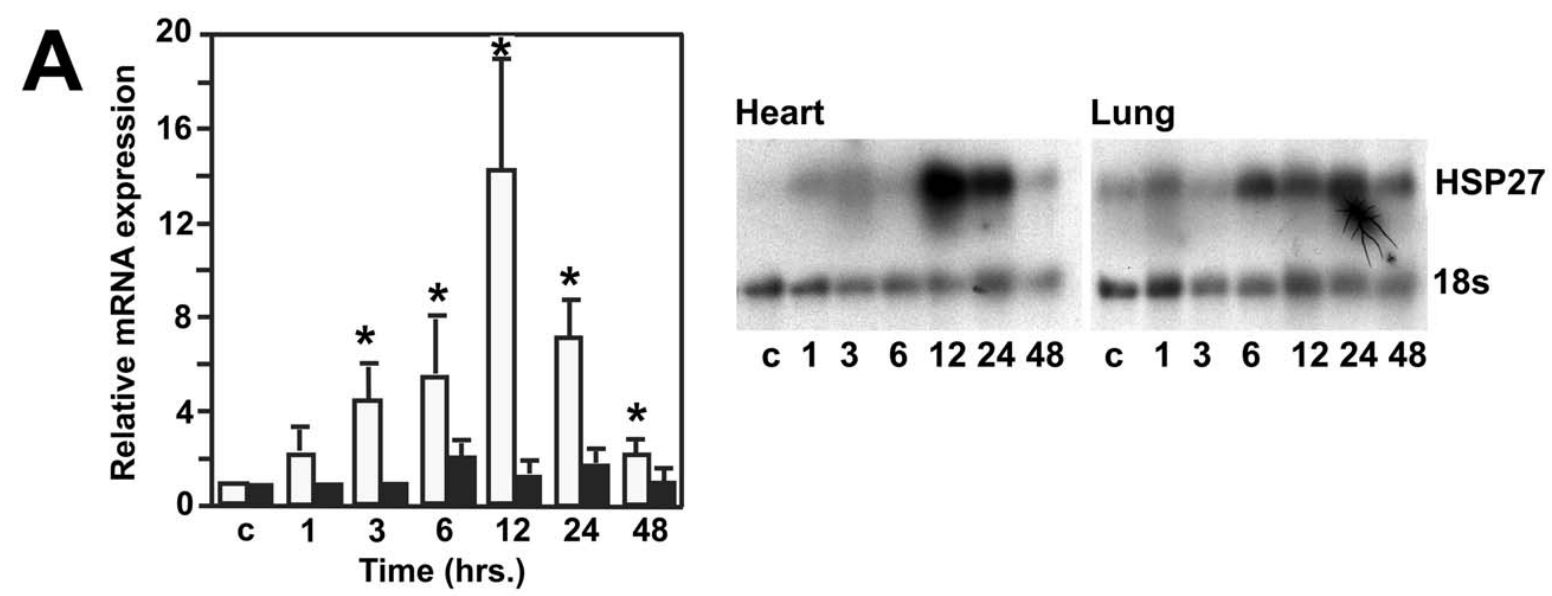

B
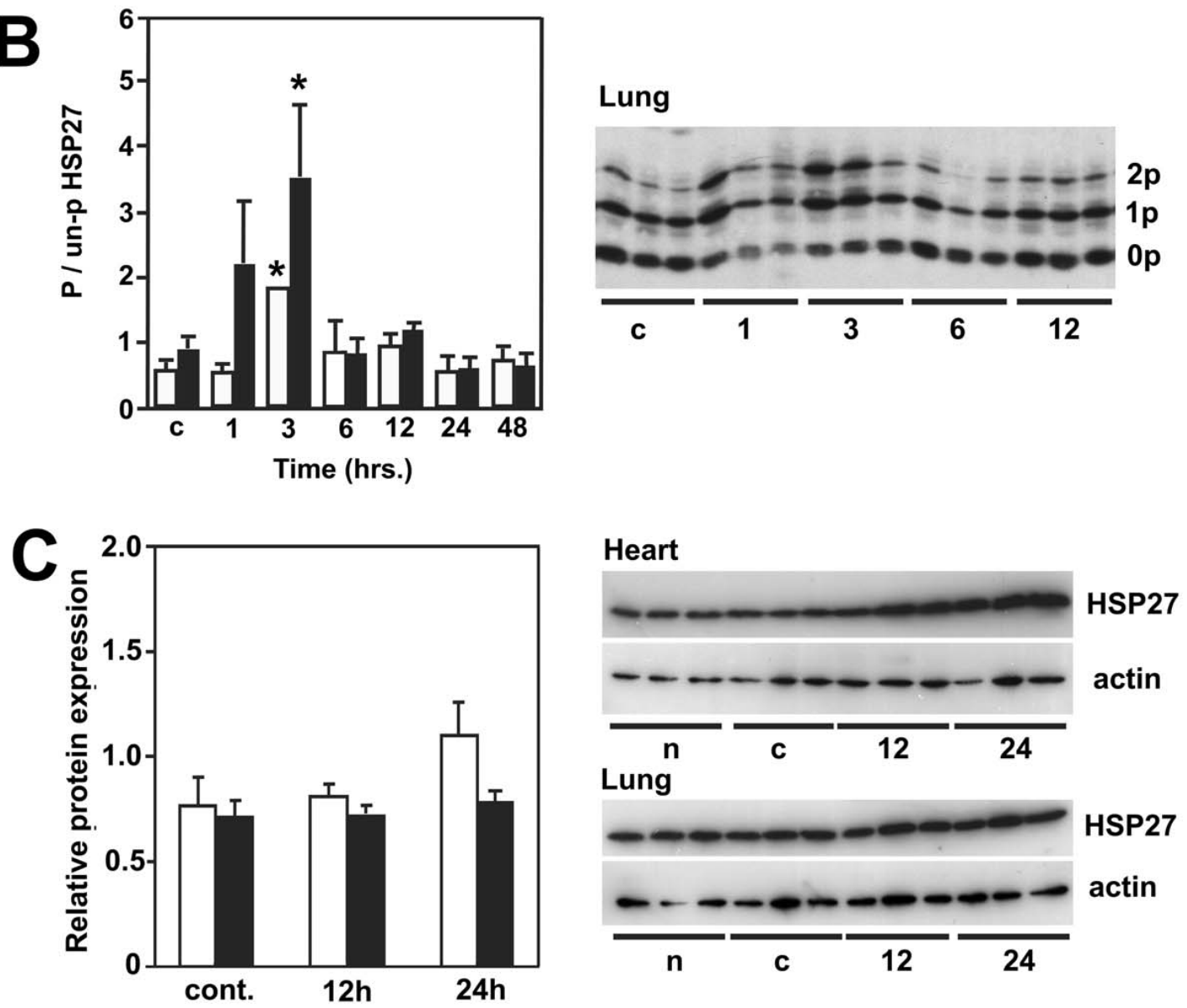


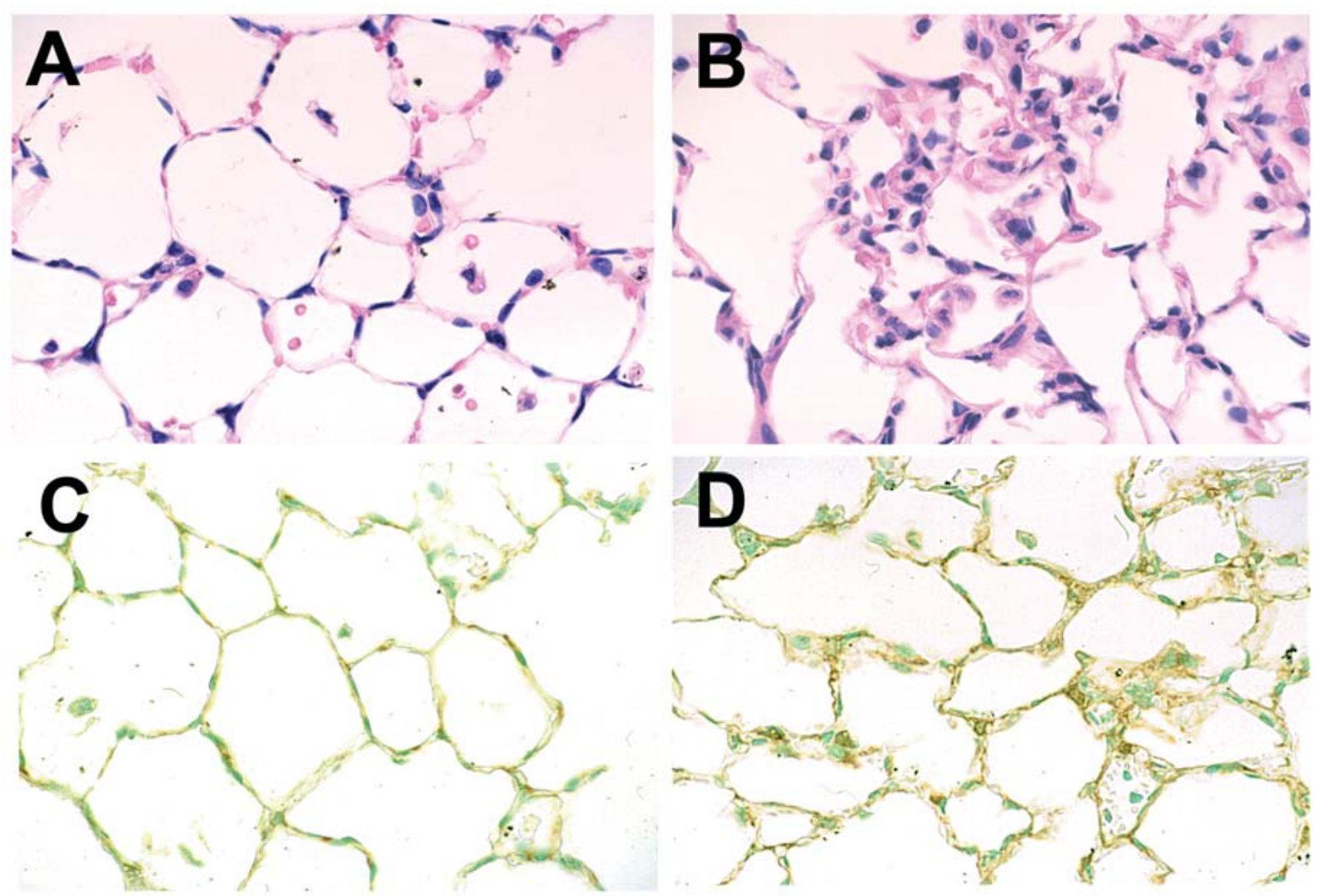

Figure 2. Histological (A, B) and immunohistological (C, D) examination of lung sections obtained from control (A, C) or LPS treated (B, D) rats. At $3 \mathrm{~h}$ after LPS injection (B), macrophage and neutrophil infiltration was observed and the alveolar wall was thickened compared to control lungs from rats injected with PBS (A). HSP27 expression was localized mainly in the endothelial cells of the alveoli and infiltrated cells were not stained (C, D).

$12 \mathrm{~h}$ after LPS injection (Figure 3A), while anti-TNF $\alpha$ antibody pretreatment inhibited LPS induced HSP27 phosphorylation at $3 \mathrm{~h}$ in both heart and lung (Figure 3B). TNF $\alpha$ activity in plasma of the rats used in this series of experiment was measured and no increase was detected in plasma TNF $\alpha$ after LPS injection in antibody-treated rats (Figure 3C). Increased HSP27 phosphorylation, which correlated with lung injury, was inhibited by anti-TNF $\alpha$ antibody pretreatment. The same anti-TNF $\alpha$ antibody treatment was reported to inhibit lung injury after LPS injection (Remick et al., 1990). Thus, HSP27 phosphorylation in lung at $3 \mathrm{~h}$ was dependent on $\mathrm{TNF} \alpha$, and it is likely that the direct causes were factors downstream of
TNF $\alpha$ because of the time difference between peaks of HSP27 phosphorylation and TNF $\alpha$ expression.

HSP27 phosphorylation in RPAEC treated with LPS, TNF, or $\mathrm{H}_{2} \mathrm{O}_{2}$

As HSP27 phosphorylation after LPS injection occurs in a manner dependent on TNF $\alpha$ in vivo, the ability of possible modulators to increase phosphorylation of HSP27 in cultured endothelial cells was investigated. $\mathrm{H}_{2} \mathrm{O}_{2}$ was used to mimic oxidant injury caused by neutrophils, which starts about $3 \mathrm{~h}$ after LPS injection (Heflin and Brigham, 1981). Treatments with LPS, TNF $\alpha$, and $\mathrm{H}_{2} \mathrm{O}_{2}$ caused 
A

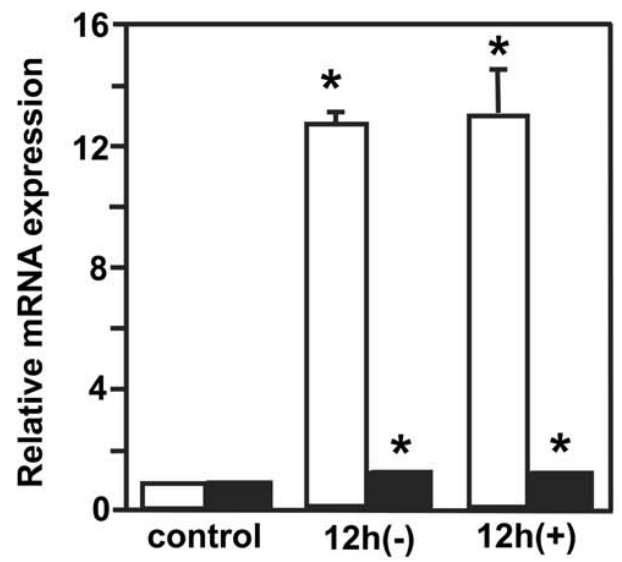

B

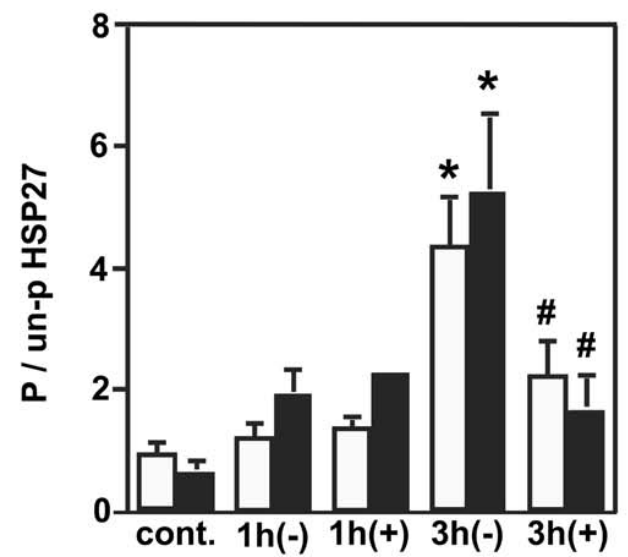

C

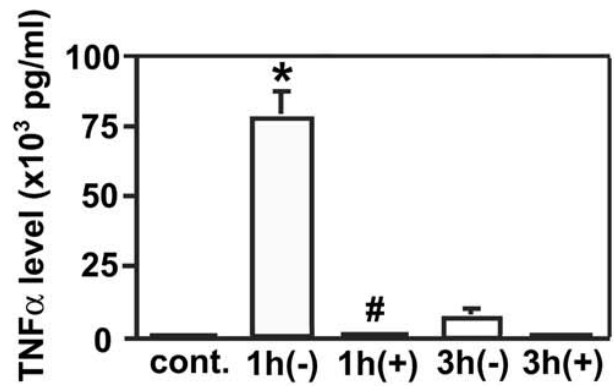

Figure 3. The effect of anti-TNF $\alpha$ antibody pre-treatment prior to LPS injection. (A) Anti-TNF $\alpha$ antibody pretreatment had no effect on increased HSP27 mRNA expression at $12 \mathrm{~h}$ after LPS injection in either heart (white) or lung (black). (B) Pretreatment with $\mathrm{TNF} \alpha$ antibody inhibited increases in HSP27 phosphorylation at $3 \mathrm{~h}$ in both heart (white) and lung (black). P/un-p represents the phosphorylation ratio (di- + mono-/unphosphorylated form). (C) Pretreatment with anti$\mathrm{TNF} \alpha$ antibody completely blocked the plasma TNF $\alpha$ activity increase at $1 \mathrm{~h}$ after LPS injection. ${ }^{*} p<0.05$ vs. control, ${ }^{\#} p<0.05$ vs. LPS only at the same time points. significant increases in HSP27 phosphorylation within $30 \mathrm{~min}$ (Figure 4A). HSP27 phosphorylation at $30 \mathrm{~min}$ caused by $\mathrm{H}_{2} \mathrm{O}_{2}$ increased in a dose dependent manner (Figure 4B). The level of phosphorylation caused by these treatments correlated with earlier observations of endothelial leakage in RPAEC cultures caused by the same treatments (Gilmont et al., 1996). When cells were pretreated with SB203580 $(20 \mu \mathrm{mol} / \mathrm{L})$, an inhibitor of p38 MAP kinase, phosphorylation of HSP27 was blocked (Figure 4C).

\section{Endothelial permeability correlated with HSP27 phosphorylation}

Although both LPS and TNF $\alpha$ caused phosphorylation of HSP27 in vivo, they are unlikely to be the direct cause of HSP27 phosphorylation in lung because of the time course considerations. In order to examine the effect of the p38 inhibitor on endothelial leakage, diffusion rates of $70 \mathrm{kDa}$ FITC-dextran across mono-layers of RPAEC were measured with or without $\mathrm{H}_{2} \mathrm{O}_{2}(200 \mu \mathrm{mol} / \mathrm{L})$ treatment. Diffusion rates were increased after treatment with $\mathrm{H}_{2} \mathrm{O}_{2}$ and this effect was blocked by pretreatment with SB203580 $(20 \mu \mathrm{mol} / \mathrm{L})$. These data indicate that endothelial leakage caused by $\mathrm{H}_{2} \mathrm{O}_{2}$ was dependent on p38 MAP kinase activity, which regulates the phosphorylation HSP27. The increases in permeability correlated with increases in phosphorylation of HSP27.

\section{Actin associated with HSP27}

To investigate the effects of phosphorylation on the association of actin and HSP27 in endothelial cells, RPAEC cultures were left untreated or were treated with $10 \mathrm{ng} / \mathrm{ml}$ LPS, $10 \mathrm{ng} / \mathrm{ml} \mathrm{TNF} \alpha$ or $200 \mu \mathrm{mol} / \mathrm{L} \mathrm{H}_{2} \mathrm{O}_{2}$ for $1 \mathrm{~h}$ prior to being harvested with IP buffer. Cell lysates were immunoprecipitated using a polyclonal antibody directed against HSP27. Immunoprecipitated proteins were subjected 

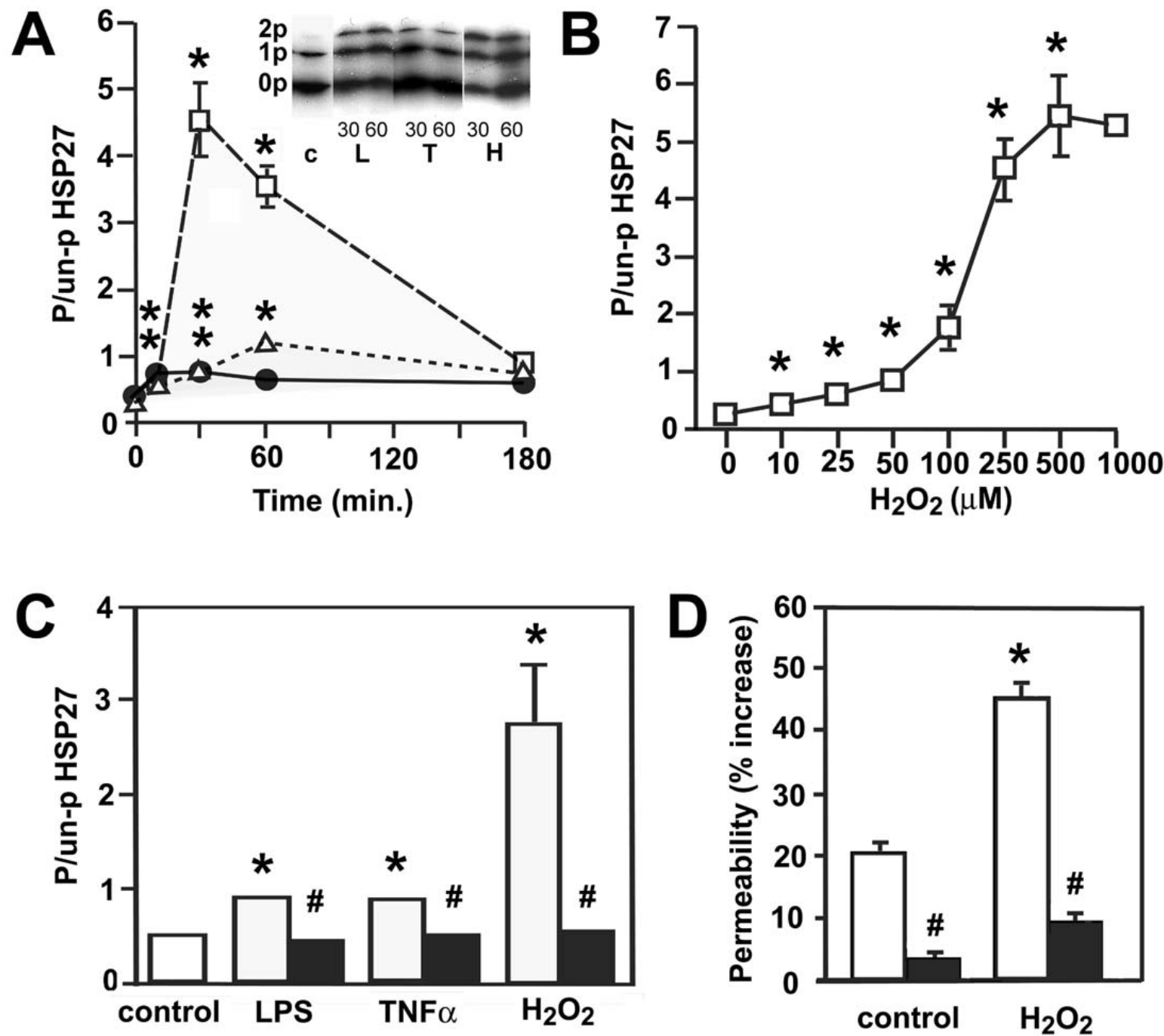

Figure 4. HSP27 phosphorylation in RPAEC cultures and permeability assay. (A) Time course of HSP27 phosphorylation after treatment with LPS (10 ng/ml) (triangle), TNF $\alpha(10 \mathrm{ng} / \mathrm{ml})$ (circle), or $\mathrm{H}_{2} \mathrm{O}_{2}(200 \mu \mathrm{mol} / \mathrm{L})$ (square). The insert shows representative patterns of three HSP27 isoforms at 30 and 60 min after treatment with LPS (L), TNF $\alpha(\mathrm{T})$ or $\mathrm{H}_{2} \mathrm{O}_{2}(\mathrm{H}) .0 \mathrm{p}, 1 \mathrm{p}$, or $2 \mathrm{p}$ represent non, mono, di-phosphorylated form of HSP27, respectively. (B) HSP27 phosphorylation status at 30 min after treatment with different dose of $\mathrm{H}_{2} \mathrm{O}_{2}$. P/un-p represents the phosphorylation ratio (di- + mono-/unphosphorylated form) $\mathrm{H}_{2} \mathrm{O}_{2}$ caused increased phosphorylation in a dose dependent manner. (C) Phosphorylation status of HSP27 at $30 \mathrm{~min}$ after treatment with LPS $(10 \mathrm{ng} / \mathrm{ml}), \mathrm{TNF} \alpha(10 \mathrm{ng} / \mathrm{ml})$, or $\mathrm{H}_{2} \mathrm{O}_{2}(200 \mu \mathrm{mol} / \mathrm{L})$, was inhibited by pretreatment with $20 \mu \mathrm{mol} / \mathrm{L} \mathrm{SB} 203580$ (black) compared to cells with no pretreatment (white). (D) Permeability across the RPAEC mono-layer cultures. Increase in permeability caused by or $\mathrm{H}_{2} \mathrm{O}_{2}(200 \mu \mathrm{mol} / \mathrm{L})$ was inhibited pretreatment with $20 \mu \mathrm{mol} / \mathrm{L} \mathrm{SB} 203580$ (black). ${ }^{*} p<0.05$ vs. control, ${ }^{\#} p<0.05$ vs. samples with the same stimulant without SB203580. 
to SDS-PAGE and Western blot analysis. Western blotting was performed using an anti$\beta$-actin antibody and the same blots were reprobed with a monoclonal anti- HSP27 antibody. Significantly less $\beta$-actin was co-precipitated with HSP27 in cultures treated with LPS or $\mathrm{H}_{2} \mathrm{O}_{2}$ (Figure $5 \mathrm{~A}$ ), while there is no difference in protein expression in cell lysates (Figure $5 \mathrm{~B}$ ). $\mathrm{H}_{2} \mathrm{O}_{2}$ treated cells had the least $\beta$-actin associated with HSP27 followed by LPS treatment and $\mathrm{TNF} \alpha$ treatment. Thus, there was an inverse relationship between HSP27 phosphorylation status and HSP27 association with actin at $1 \mathrm{~h}$ post-treatment.

\section{Discussion}

In this study, we have demonstrated significantly increased HSP27 phosphorylation in the lungs at $3 \mathrm{~h}$ after rats were treated with a low dose of LPS. This time-course coincides with the initiation of lung injury after LPS treatment (Koh et al., 1999). It is generally accepted that the retention of neutrophils or macrophages is responsible for the greatest portion of sepsis induced lung injury in endotoxemia (Worthen et al., 1987). Granulocyte depletion has been shown to block the large increase in lung permeability after $3 \mathrm{~h}$ (Heflin and Brigham, 1981). Kang and colleagues reported that monocytes containing peroxidase-positive granules adhered to endothelial cells at $3 \mathrm{~h}$ post treatment (Kang and Williams, 1991). These observations suggest that by $3 \mathrm{~h}$ post treatment leukocytes start to play a major role by producing reactive oxygen species. Because HSP27 phosphorylation was significantly increased in the lung by $3 \mathrm{~h}$ post LPS injection, HSP27 phosphorylation appears to share the same time course as the initiation of endothelial gap formation in lung injury. HSP27 phosphorylation peaked at $3 \mathrm{~h}$, while lung edema persisted up to $24 \mathrm{~h}$ as determined by $H \& E$ staining (data not shown). Therefore

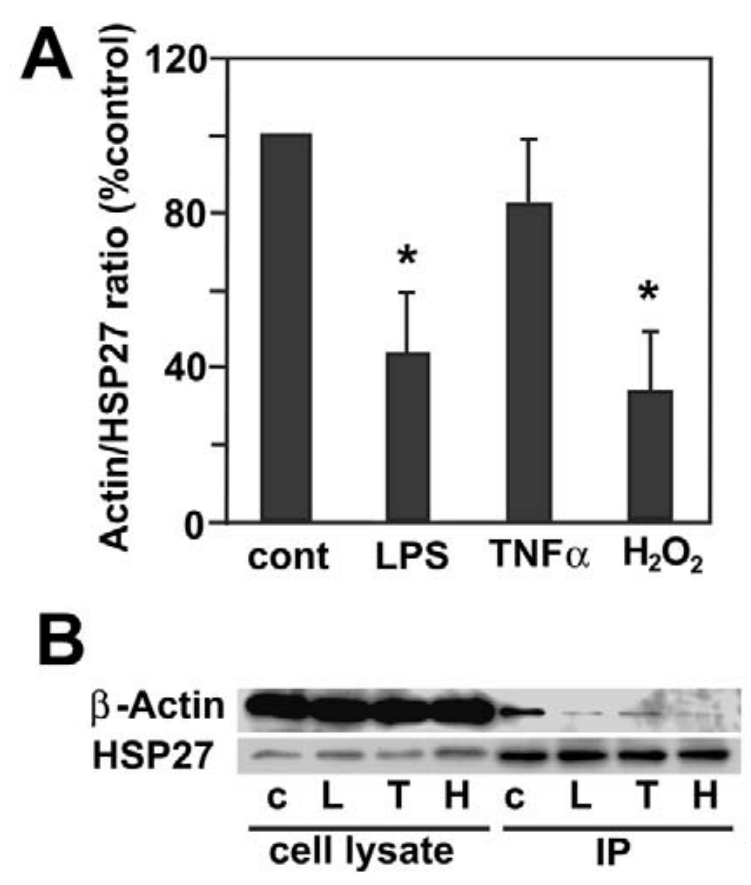

Figure 5. Ratio of actin associated to HSP27 in RPAEC treated with LPS $(10 \mathrm{ng} / \mathrm{ml}), \mathrm{TNF} \alpha(10 \mathrm{ng} / \mathrm{ml})$, or $\mathrm{H}_{2} \mathrm{O}_{2}(200 \mu \mathrm{mol} / \mathrm{L})$ for $1 \mathrm{~h}$. (A) The ratio of band densities of $\beta$-actin to HSP27 normalized to control in each experiment is shown. ${ }^{*} p<0.05$ vs. control . (B) A representative western blot. The same blots were used for Western blotting for HSP27 and $\beta$-actin.

HSP27 phosphorylation was temporally correlated with the initiation of endothelial gap formation in vivo. Since enhanced HSP27 phosphorylation at $3 \mathrm{~h}$ in lung or heart was inhibited by anti-TNF $\alpha$ antibody pretreatment, HSP27 phosphorylation at $3 \mathrm{~h}$ was due to direct or indirect effects of $\mathrm{TNF} \alpha$. The mediators of indirect effect of $\mathrm{TNF} \alpha$ may be cytokines such as interleukins induced by $\mathrm{TNF} \alpha$, or reactive oxygen species produced by infiltrated neutrophils. Anti-TNF $\alpha$ antibody pretreatment has been shown to inhibit lung edema (Seekamp et al., 1993) and neutrophil infiltration in the lung after LPS treatment (Remick et al., 1990). The reduction in HSP27 phosphorylation seen in this study correlated with the reduction of lung edema caused by anti-TNF $\alpha$ antibody treatment. TNF $\alpha$ has been reported 
to cause endothelial cell injury and gap formation of cultured endothelial cells when administrated at the same dose used in this study (Goldblum et al., 1993). In tissue culture, the peak phosphorylation of HSP27 caused by TNF $\alpha$ or LPS occurred at $30 \mathrm{~min}$ or $1 \mathrm{~h}$ after treatment, respectively. In vivo, HSP27 phosphorylation peaked at $3 \mathrm{~h}$ after LPS injection, a full $2 \mathrm{~h}$ after the plasma TNF $\alpha$ concentration had peaked. These results imply that the effect of TNF $\alpha$ after LPS treatment on HSP27 phosphorylation in vivo was indirect. $\mathrm{TNF} \alpha$ is known to induce cytokines such as interleukin-1 (IL-1), IL-6 and IL-8, and to mediate neutrophil infiltration (Remick et al., 1990). HSP27 is phosphorylated in response to treatment with IL-1 (Kaur et al., 1989), TNF $\alpha$, or $\mathrm{H}_{2} \mathrm{O}_{2}$ in cultured cells. In this study, we did not determine the role of other cytokines that can regulate neutrophil infiltration. Although it is possible that interleukins directly caused HSP27 phosphorylation in the endothelial cells, it is more likely that oxidant injury caused by neutrophils contributed to phosphorylation as there was neutrophil infiltration by $3 \mathrm{~h}$ in lung.

Steady state levels of HSP27 mRNA were substantially increased in the heart and only slightly increased in the lung, which did not lead to increased protein expression in either organ. LPS injection caused an increase in HSP27 mRNA of up to 14.5-fold in the heart in this study, which was more dramatic than increases reported for the induction of beta myosin heavy chain ( $\beta M H C)$ mRNA (Macallan and Griffin, 1994). Anti-TNF $\alpha$ antibody had no effect on increases in HSP27 mRNA in this study, or on $\beta M H C$ mRNA in the heart following LPS injection (Macallan and Griffin, 1994). The minimal induction of HSP27 in lung compared to heart may be due to the different cell types in both organs and may relate to the severity of tissue insult, as increased expression of HSP27 has been shown to protect cells from damage (Lavoie et al., 1993b). It is also shown that pretreatment with heat shock decreased LPSinduced acute lung injury of rats (Koh et al., 1999). In this study, mRNA induction after LPS injection was independent of TNF $\alpha$ or the severity of the injury.

Because we examined phosphorylation of HSP27 using whole tissue, it is likely that the protein is from a mixed cell population. It has been reported that HSP27 mRNA mainly localizes in smooth muscle of arteries in rat lung by in situ hybridization (Wakayama and Isek, 1998). We observed staining in endothelial cells of alveoli as well as intense staining in smooth muscle cells. Because endothelial cells are the largest cell population in parenchymal tissue followed by interstitial cells (Haies et al., 1981), we consider endothelial cells to be a major source of HSP27 in the lung.

In the tissue culture model using endothelial cells from pulmonary arteries of rats, increased permeability caused by $\mathrm{H}_{2} \mathrm{O}_{2}$ was blocked by pretreatment with the inhibitor of p38 MAP kinase. In these studies, we measured the permeability over a period of $30 \mathrm{~min}$ before and after a $1 \mathrm{~h}$ treatment with $\mathrm{H}_{2} \mathrm{O}_{2}$. After treatment with $200 \mu \mathrm{mol} / \mathrm{L} \mathrm{H}_{2} \mathrm{O}_{2}$, phosphorylation of HSP27 peaks at $30 \mathrm{~min}$, while endothelial leakage continues to increase over time. This sequence of events appears to be similar to the in vivo observations with LPS treatment. At 60 to 90 min after treatment with $\mathrm{H}_{2} \mathrm{O}_{2}, 70 \mathrm{kD}$-dextran leaked through endothelial cell monolayers significantly more than control, and this process was blocked by inhibition of p38 MAP kinase activity. These data demonstrate that the endothelial leakage caused by $\mathrm{H}_{2} \mathrm{O}_{2}$ was regulated by p38 MAP kinase, and is consistent with other studies (Huot et al., 1997; Kevil et al., 2001). $\mathrm{H}_{2} \mathrm{O}_{2}$ induced phosphorylation of HSP27 was blocked by p38 MAP kinase inhibition as well, and the phosphorylation status of HSP27 correlated with the severity of barrier dysfunction. These results support the possibility that HSP27 is an effecter of p38 MAP kinase. 
The molecular mechanism(s) of HSP27 activity is still unclear, but a great body of literature suggests its ability to modulate microfilaments as a major function. The amount of $\beta$-actin co-immunoprecipitated with HSP27 decreased after treatment with $\mathrm{H}_{2} \mathrm{O}_{2}$ or LPS. This data suggested that HSP27 dissociated from actin upon phosphorylation. A dissociation of HSP27 and actin could promote cell contraction. This finding is consistent with the observation that only unphosphorylated HSP27 binds to microfilaments and inhibits actin polymerization in vitro (Benndorf et al., 1994). Although the inhibitor of p38 MAP kinase inhibits endothelial leakage caused by $\mathrm{H}_{2} \mathrm{O}_{2}$, the molecular mechanism is not clear. Petrache and colleagues suggested the role of p38 MAP kinase in destabilization of microtubules on TNF $\alpha$-induced endothelial barrier dysfunction (Petrache et al., 2003). The role of myosin and myosin light chain kinase (MLCK) has been suggested for the mechanism of endothelial cytoskeletal rearrangement after treatment with $\mathrm{H}_{2} \mathrm{O}_{2}$ (Zhao et al., 1998). Endothelial barrier dysfunction caused by histamine or thrombin was dependent on changes in cell-matrix adhesion and independent of MLCK activation. Recovery was dependent on MLCK activity, which correlated with cellcell adhesion (Moy et al., 2002). In sodium fluoride-induced endothelial barrier dysfunction, MLC phosphorylation was essential and regulated primarily by RhoK and not MLCK (Wang et al., 2001). In this report, we did not identify the mechanism(s) of p38 MAP kinase or HSP27 action, but showed a strong correlation between HSP27 phosphorylation and endothelial gap formation both in vivo and in a tissue culture model of sepsis-induced pulmonary edema.

\section{Acknowledgment}

We thank Dr Rainer Benndorf for valuable advice in preparation of the manuscript. This work was supported by a grant from the National Institute of Environmental Health Sciences (PO1 ES11188, MJ Welsh, PI), and by funding from the University of Michigan Department of Surgery Research Advisory Committee (RRG) and a VA Merit Review Grant (RSR).

\section{References}

Alexander JS, Hechtman HB Shepro D. Phalloidin enhances endothelial barrier function and reduces inflammatory permeability in vitro. Microvasc Res. 1988;35:308-15.

Arrigo AP. Tumor necrosis factor induces the rapid phosphorylation of the mammalian heat shock protein hsp28 [published erratum appears in Mol Cell Biol. 1990;10:38-57]. Mol Cell Biol. 1990;10:1276-80.

Benndorf R, Hayess K, Ryazantsev S, Wieske M, Behlke J, Lutsch G. Phosphorylation and supramolecular organization of murine small heat shock protein HSP25 abolish its actin polymerization-inhibiting activity. J Biol Chem. 1994; 269:20780-4.

Beutler B, Milsark IW, Cerami AC. Passive immunization against cachectin/tumor necrosis factor protects mice from lethal effect of endotoxin. Science. 1985;229:869-71.

Bitar KN, Kaminski MS, Hailat N, Cease KB, Strahler JR. Hsp27 is a mediator of sustained smooth muscle contraction in response to bombesin. Biochem Biophys Res Commun. 1991;181:1192-200.

Chomczynski P, Sacchi N. Single-step method of RNA isolation by acid guanidinium thiocyanate- phenol-chloroform extraction. Anal Biochem. 1987;162:156-9.

Eskandari MK, Nguyen DT, Kunkel SL, Remick DG. WEHI 164 subclone 13 assay for TNF: sensitivity, specificity, and reliability. Immunol Invest. 1990;19:69-79.

Garcia JG, Wang P, Schaphorst KL, et al. Critical involvement of $\mathrm{p} 38$ MAP kinase in pertussis toxin-induced cytoskeletal reorganization and lung permeability. FASEB J. 2002;16: 1064-76.

Gilmont RR, Dardano A, Engle JS, et al. TNF-alpha potentiates oxidant and reperfusion-induced endothelial cell injury. J Surg Res. 1996;61:175-82.

Goldblum SE, Ding X, Campbell-Washington J. TNF-alpha induces endothelial cell F-actin depolymerization, new actin synthesis, and barrier dysfunction. Am J Physiol. 1993;264: C894-905.

Haies D, Gil J, Weibel E. Morphometric study of rat lung cells. I. Numerical and dimensional characteristics of parenchymal cell population. Am Rev Respir Dis. 1981;123:533-41.

Heflin AC Jr, Brigham KL. Prevention by granulocyte depletion of increased vascular permeability of sheep lung following endotoxemia. J Clin Invest. 1981;68:1253-60.

Horvath CJ, Ferro TJ, Jesmok G, Malik AB. Recombinant tumor necrosis factor increases pulmonary vascular perme- 
ability independent of neutrophils. Proc Natl Acad Sci USA. 1988;85:9219-23.

Huot J, Houle F, Marceau F, Landry J. Oxidative stressinduced actin reorganization mediated by the $\mathrm{p} 38$ mitogenactivated protein kinase/heat shock protein 27 pathway in vascular endothelial cells. Circ Res. 1997;80:383-92.

Kang YH, Williams R. Endotoxin-induced endothelial injury and subendothelial accumulation of fibronectin in rat aorta. Anat Rec. 1991;229:86-102.

Kaur P, Welch WJ, Saklatvala J. Interleukin 1 and tumour necrosis factor increase phosphorylation of the small heat shock protein. Effects in fibroblasts, Hep G2 and U937 cells. FEBS Lett. 1989;258:269-73.

Kevil CG, Oshima T, Alexander JS. The role of p38 MAP kinase in hydrogen peroxide mediated endothelial solute permeability. Endothelium. 2001;8:107-16.

Koh Y, Lim CM, Kim MJ, et al. Heat shock response decreases endotoxin-induced acute lung injury in rats. Respirology. 1999;4:325-30.

Lavoie JN, Hickey E, Weber LA, Landry J. Modulation of actin microfilament dynamics and fluid phase pinocytosis by phosphorylation of heat shock protein 27. J Biol Chem. 1993a;268:24210-4.

Lavoie JN, Gingras-Breton G, Tanguay RM, Landry J. Induction of Chinese hamster HSP27 gene expression in mouse cells confers resistance to heat shock. HSP27 stabilization of the microfilament organization. J Biol Chem. 1993b;268: $3420-9$.

Lavoie JN, Lambert H, Hickey E, Weber LA, Landry J. Modulation of cellular thermoresistance and actin filament stability accompanies phosphorylation-induced changes in the oligomeric structure of heat shock protein 27. Mol Cell Biol. 1995;15:505-16.

Louis SR, Lewis VR. Quantitation of microgram amounts of protein in two demensional polyacrylamide gel electrophoresis sample buffer. Electrophoresis. 1985;6:559-63.

Luna EJ Hitt AL. Cytoskeleton-plasma membrane interactions. Science. 1992;258:955-64.

Lutsch G, Vetter R, Offhauss U, et al. Abundance and location of the small heat shock proteins HSP25 and alphaB-crystallin in rat and human heart. Circulation. 1997;96:3466-76.

Macallan DC, Griffin GE. Cardiac muscle protein gene expression in the endotoxin-treated rat. Clin Sci (Colch). 1994;87: 539-46.

Martin MA, Silverman HJ. Gram-negative sepsis and the adult respiratory distress syndrome. Clin Infect Dis. 1992;14: 1213-28.

Mendelsohn ME, Zhu Y, O'Neill S. The 29-kDa proteins phosphorylated in thrombin-activated human platelets are forms of the estrogen receptor-related $27-\mathrm{kDa}$ heat shock protein. Proc Natl Acad Sci USA. 1991;88:11212-6.

Miron T, Vancompernolle K, Vandekerckhove J, Wilchek M, Geiger B. A $25-\mathrm{kD}$ inhibitor of actin polymerization is a low molecular mass heat shock protein. J Cell Biol. 1991;114: 255-61.

Moy AB, Blackwell K, Kamath A. Differential effects of histamine and thrombin on endothelial barrier function through actin-myosin tension. Am J Physiol Heart Circ Physiol. 2002;282:H21-9.
Petrache I, Birukawa A, Ramirez SI, Garcia JGN, Verin AD. The role of the microtubules in tumore necrosis factor- $\alpha$ induced endothelial cell permeability. Am J Respir Cell Mol Biol. 2003;28:574-81

Phillips PG, Lum H, Malik AB, Tsan MF. Phallacidin prevents thrombin-induced increases in endothelial permeability to albumin. Am J Physiol. 1989;257:C562-7.

Remick DG, Strieter RM, Eskandari MK, et al. Role of tumor necrosis factor-alpha in lipopolysaccharide-induced pathologic alterations. Am J Pathol. 1990;136:49-60.

Robaye B, Hepburn A, Lecocq R, Fiers W, Boeynaems JM, Dumont JE. Tumor necrosis factor-alpha induces the phosphorylation of $28 \mathrm{kDa}$ stress proteins in endothelial cells: possible role in protection against cytotoxicity? Biochem Biophys Res Commun. 1989;163:301-8.

Seekamp A, Warren JS, Remick DG, Till GO, Ward PA. Requirements for tumor necrosis factor-alpha and interleukin-1 in limb ischemia/reperfusion injury and associated lung injury. Am J Pathol. 1993;143:453-63.

Shasby DM, Shasby SS, Sullivan JM, Peach MJ. Role of endothelial cell cytoskeleton in control of endothelial permeability. Circ Res. 1982;51:657-61.

Smoyer WE, Gupta A, Mundel P, Ballew JD, Welsh MJ. Altered expression of glomerular heat shock protein 27 in experimental nephrotic syndrome. J Clin Invest. 1996;97: 2697-704

Szyf M, Milstone DS, Schimmer BP, Parker KL, Seidman JG. cis modification of the steroid 21-hydroxylase gene prevents its expression in the Y1 mouse adrenocortical tumor cell line. Mol Endocrinol. 1990;4:1144-52.

Takeichi M. Cadherins: a molecular family important in selective cell-cell adhesion. Annu Rev Biochem. 1990;59: 237-52.

Tracey KJ, Fong Y, Hesse DG, et al. Anti-cachectin/TNF monoclonal antibodies prevent septic shock during lethal bacteraemia. Nature. 1987;330:662-4.

Wakayama T, Isek IS. Expression and cellular localization of the mRNA for the 25-kDa heat-shock protein in the mouse. Cell Biol Int. 1998;22: 295-304.

Wang P, Verin AD, Birukova A, Gilbert-McClain LI, Jacobs K, Garcia JG. Mechanisms of sodium fluoride-induced endothelial cell barrier dysfunction: role of MLC phosphorylation. Am J Physiol Lung Cell Mol Physiol. 2001;281: L1472-83.

Worthen GS, Haslett C, Rees AJ, Gumbay RS, Henson JE, Henson PM. Neutrophil-mediated pulmonary vascular injury. Synergistic effect of trace amounts of lipopolysaccharide and neutrophil stimuli on vascular permeability and neutrophil sequestration in the lung. Am Rev Respir Dis. 1987;136:19-28.

Zhao Y, Davis HW. Hydrogen peroxide-induced cytoskeletal rearrangement in cultured pulmonary endothelial cells. J Cell Physiol. 1998;174:370-9.

Address for correspondence: Sahoko Hirano, Department of Cell and Developmental Biology, University of Michigan Medical Center, 1335 Catherine Street, Ann Arbor, MI 481090616, USA.

E-mail: hsahoko@hotmail.com 